\title{
Maintaining remission in distal ulcerative colitis and ulcerative proctitis
}

PB MINER JR, MD, WL BIDDLE, RN, PHD

\begin{abstract}
Maintenance of remission is an important consideration in the medical care of patients with ulcerative colitis. The relapse rate is high when medications are discontinued. Many types of medications have been investigated for potential efficacy of maintaining remission. This paper reviews the literature on maintenance therapy for both distal and universal ulcerative colitis. Sulphasalazine is the drug of choice since it is effective and relatively low in cost. 5-aminosalicylic acid (5-ASA) derivatives, both oral and rectal forms, are also effective. Other medications such as metronidazole, cromolyn sodium and prednisone have not been shown to be effective maintenance therapy. Strategies for maintenance are outlined and include possible regimens with 5-ASA enemas. While $1 \mathrm{~g}$ of 5 -ASA is effective, the long term relapse rate is similar to that seen with sulphasalazine. Patients tapered to $1 \mathrm{~g} 5$-ASA enemas have a good chance of maintaining remission if the colitis does not flare within the first few months, because most colites will flare up early on. Other possible regimens include intermittent enemas, eg, every other night or every third night. Patients in remission can be safely maintained in remission with sulphasalazine or one of its 5-ASA derivatives. Can J Gastroenterol 1990;4(7):476-480 (pour résumé, voir page 477)
\end{abstract}

Key Words: Aminosalicylates, Maintenance therapy, Topical therapy, Ulcerative colitis

University of Kansas Medical Center, Kansas City, Kansas, USA

Correspondence and reprints: Dr PB Miner Jr, Associate Professor, Director, Division of Gastroenterology, University of Kansas Medical Center, 39th and Rainbow Boulevard, Kansas City, KS 66103, USA. Telephone (913) 588-6003
HRONIC ULCERATIVE COLITIS is
an inflammatory disease of the colon which has longstanding consequences both in symptoms and in the need for management. As treatment evolved from the 1930 s to the 1950 s, sulphasalazine became established as a prominent medication for the management of acute ulcerative colitis beginning with the works of Morrison, Moertel, Bargen and Svartz (1-3). Once its value in acute disease was recognized, numerous studies were done to evaluate the effectiveness of sulphasalazine and other medications for maintaining remission.

\section{EFFECTIVE MAINTENANCE THERAPY}

Frequent relapses of ulcerative colitis occur after discontinuation of sulphasalazine treatment. Each point in Figure 1 represents the percentage of patients in remission at specific time 


\section{Maintien des rémissions dans la colite ulcéreuse distale et la rectite ulcéreuse}

RESUME: Le maintien des rémissions est une considération importante dans le traitement médical des patients atteints de colite ulcéreuse. Le taux de récidive est élevé à l'arrêt du traitement. De nombreux types de médicament ont été étudiés pour déterminer leur efficacité potentielle dans le maintien des rémissions. Cet article passe en revue la littérature traitant du sujet dans la colite ulcéreuse distale et universelle. Son efficacité et son coût modique font de la sulfasalazine le premier médicament de choix. Les dérivés de l'acide 5 aminosalicylique (5-ASA), sous formes orales et rectales, sont également efficaces. D'autres substances - le métronidazole, le cromoglycate disodique et la prednisone notamment - n'ont pas prouvé leur efficacité dans le traitement d'entretien. Les stratégies de maintien sont décrites; elles incluent peut-être les lavements de 5-ASA. S'il est vrai que $1 \mathrm{~g}$ de 5-ASA est efficace, le taux de récidive à long terme est similaire à celui de la sulfasalazine. Chez les patients dont la posologie est progressivement réduite à des lavements de $1 \mathrm{~g}$ de 5-ASA, la probabilité du maintien des rémissions est bonne si la colite ne récidive pas au cours des premiers mois, car il est caractéristique que les patients subissent des poussées rapidement. Les lavements intermittents - tous les deux ou trois soirs figurent parmi les autres traitements possibles. Les patients peuvent prolonger leurs rémissions en toute sécurité avec la sulfasalazine ou un des dérivés du 5-ASA.

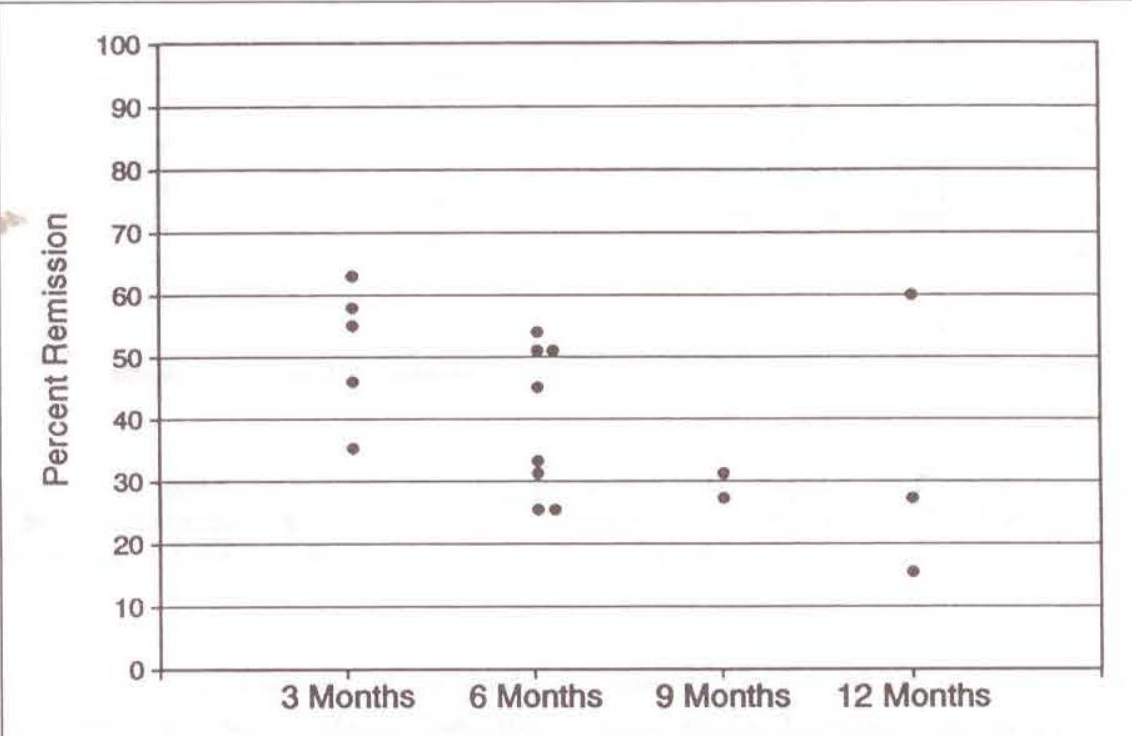

Figure 1) Percentage of patients maintained in remission on placebo in controlled clinical trials of maintenance therapy for ulcerative colitis. (Data are from references 4-12)

intervals after beginning the placebo arm of trials of maintenance therapy for ulcerative colitis (4-12). The trials differ in disease documentation and in the definitions of maintenance of remission, making comparisons difficult. Despite this limitation, the trend clearly shows frequent disease recurrence throughout a 12 month period. The mean percentage of patients in remission is $51 \%$ at three months, $39 \%$ at six months, $29 \%$ at nine months, and $34 \%$ at 12 months, confirming an increasing risk of relapse with time. The data illustrate the need for effective maintenance therapy in chronic ulcerative colitis.

\section{SULPHASALAZINE}

The improved percentages of patients in remission after sulphasalazine are superimposed over the placebo results in Figure 2 (13-25). All doses of sulphasalazine increased the percentage of patients in remission. The remission rate at six months is $82 \%$ with $4 \mathrm{~g}$ sulphasalazine and $81 \%$ with $3 \mathrm{~g}$. One study evaluated 1,2 and $4 \mathrm{~g}$ doses of sulphasalazine (16). The percentage of patients in remission at the end of six months was $88 \%$ on $2 \mathrm{~g}$ and $67 \%$ on $1 \mathrm{~g}$. This study has been the basis for the recommendation that $2 \mathrm{~g}$ sulphasalazine is the minimum recommended dose to maintain remission.

\section{5-AMINOSALICYLIC ACID}

In 1977 Azad-Khan et al (26) demonstrated that 5-aminosalicylic acid (5-ASA) is the active component of sulphasalazine (26). Since that time, rectally administered suppositories and enemas and special oral formulations of 5-ASA have been studied to determine their effectiveness in inducing remission in ulcerative colitis. Few studies have focused on maintenance of remission, though all of the 5-ASA compounds produce excellent results compared to placebo, with the exception of 5-ASA suppositories which have only been examined in one maintenance study (Figure 3$)(5,11,18,20-24)$.

Figure 4 illustrates the results of all studies using 5-ASA and sulphasalazine. In this combined data, both 5-ASA and its parent compound sulphasalazine appear equally effective in maintaining remission in ulcerative colitis.

\section{OTHER MEDICATIONS}

Several other drugs have been tried in an attempt to maintain patients with ulcerative colitis in remission. The experimental circumstances and the controls vary markedly in all of these studies; however, Figure 5 illustrates the relatively unimpressive results obtained with levamisole, cromolyn, metronidazole, PRD 92 (a mast cell stabilizer) and prednisone compared with the accumulated placebo controls $(4,9$, $10,12,14,17,25)$.

Caution should be used in interpreting this summary as the figure serves only to present an overview of the medications that have been examined. 


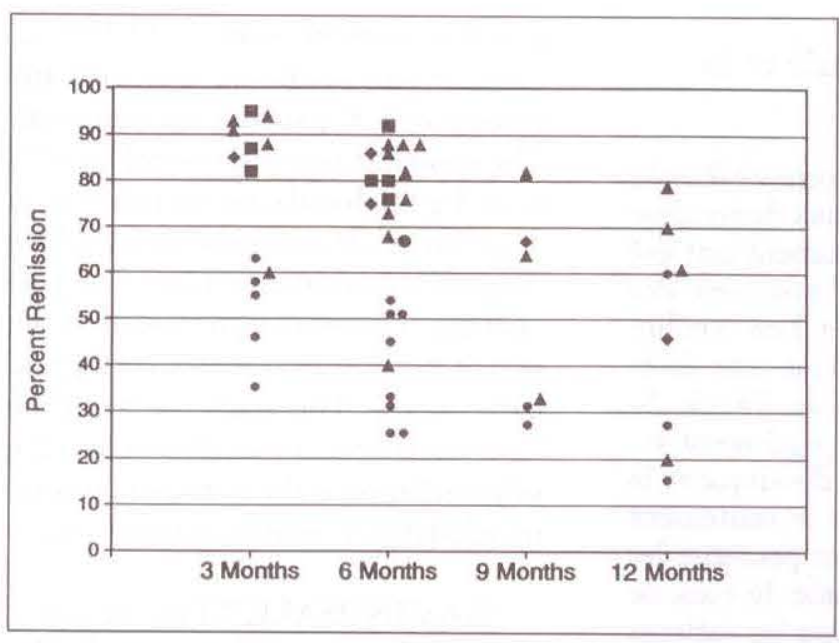

Figure 2) Percentage of patients maintained in remission on sul-

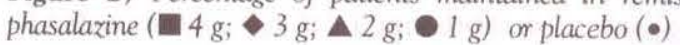

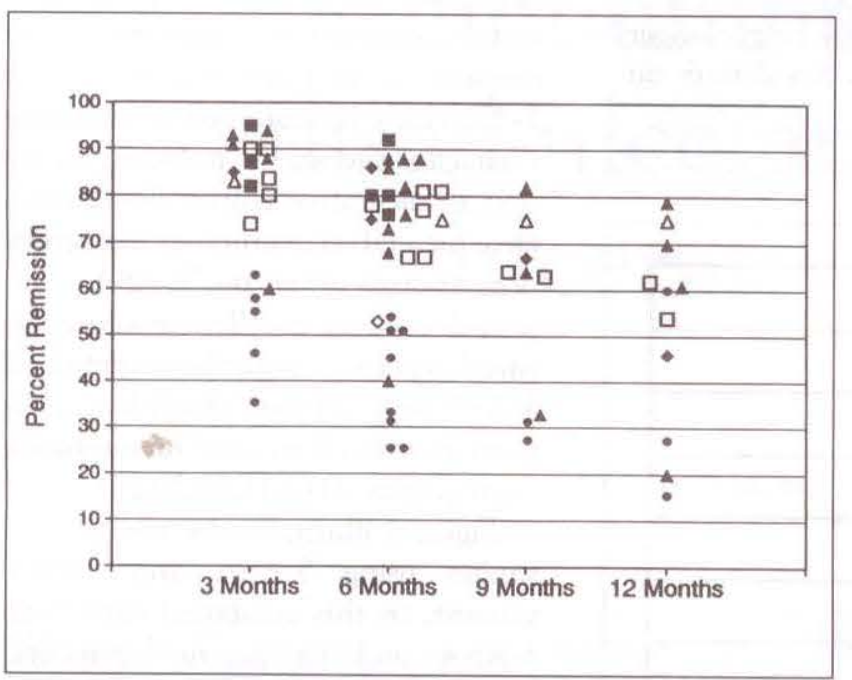

Figure 4) Percentage of patients maintained in remission on 5-ASA ( $\square$ oral; $\Delta$ enema; $\bigcirc$ suppository), sulphasalazine ( $4 \mathrm{~g} ; \quad 3 \mathrm{~g} ; \mathbf{\Delta} 2 \mathrm{~g} ; \square$ $1 \mathrm{~g})$ or placebo $(\bullet)$

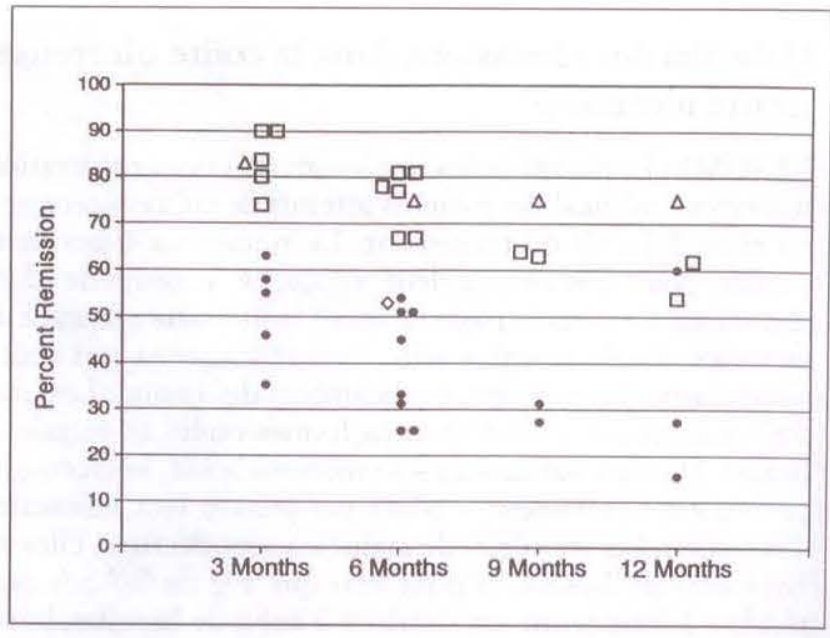

Figure 3) Percentage of patients maintained in remission on 5-ASA ( $\square$ oral; $\Delta$ enema; $\diamond$ suppository) or placebo $(\bullet)$

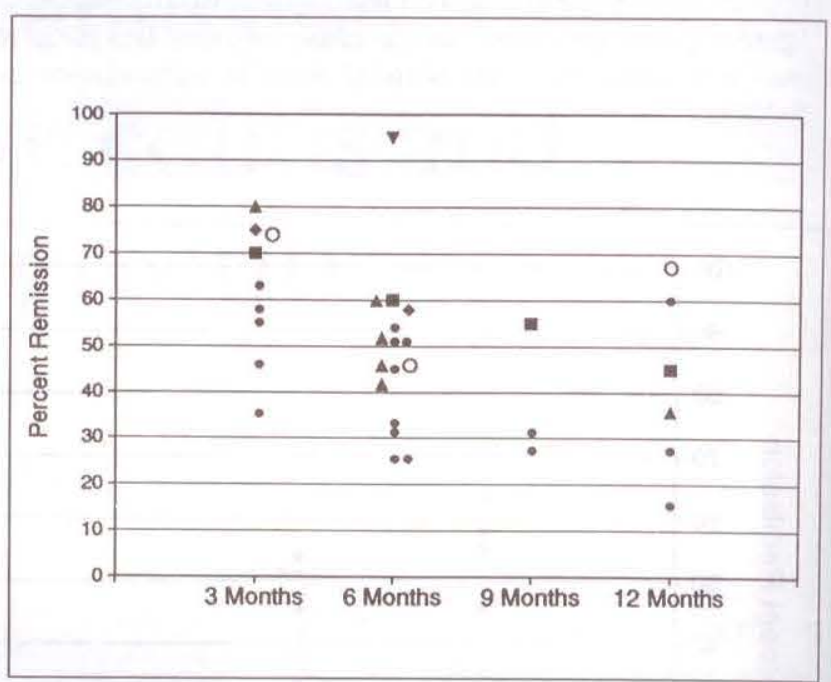

Figure 5) Percentage of patients maintained in remission on various

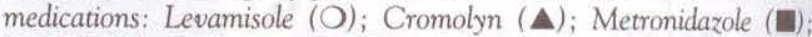
PRD92 ( ); Prednisone (O $15 \mathrm{mg}$ daily; $40 \mathrm{mg}$ daily); placebo (•)

\section{STRATEGIES FOR MAINTAINING REMISSION}

Several strategies for maintaining remission in distal ulcerative colitis have evolved (Figure 6). Since 5-ASA is the most effective agent for maintaining remission, treatment should be tailored to suit the individual variation in disease severity and resistance to treatment. The most cost efficient regimen to maintain remission is $2 \mathrm{~g}$ of sulphasalazine per day at a current cost of less than $\$ 0.50$ per day, as $88 \%$ of patients will be in remission at six months (16). 5-ASA formulations may be able to provide a higher concentration of active drug in the colon through direct application by enema or suppository or with delayed release oral forms of the drug. The authors evaluated retrospectively the success of maintaining remission in all patients who achieved remission with $4 \mathrm{~g} 5$. ASA enemas. These patients were then placed on either $1 \mathrm{~g} 5$-ASA enemas or $2 \mathrm{~g}$ sulphasalazine. This group of patients had longstanding disease and were referred to the authors by either internists or gastroenterologists after failing to respond to treatment. They represented a group of patients with relatively resistant disease. Figure 7 compares the 12 month remission rate for patients on $1 \mathrm{~g}$ 5-ASA or $2 \mathrm{~g}$ sul- phasalazine. Relapse on $1 \mathrm{~g}$ 5-ASA occurs early as the curve levels out after four months. The pattern for sulphasalazine is similar. There appears to be a trend towards a lower remission rate with sulphasalazine treatment; however there was no statistical difference in the number of patients in remission after one year.

The authors recently reported the results of a double-blind, placebo controlled trial of $1 \mathrm{~g} 5$-ASA enemas in the management of remission (5). The reason the results of the authors' blinded trial were superior to their open label trial is not clear. Since it was pos. sible the patients in the active drug arm 


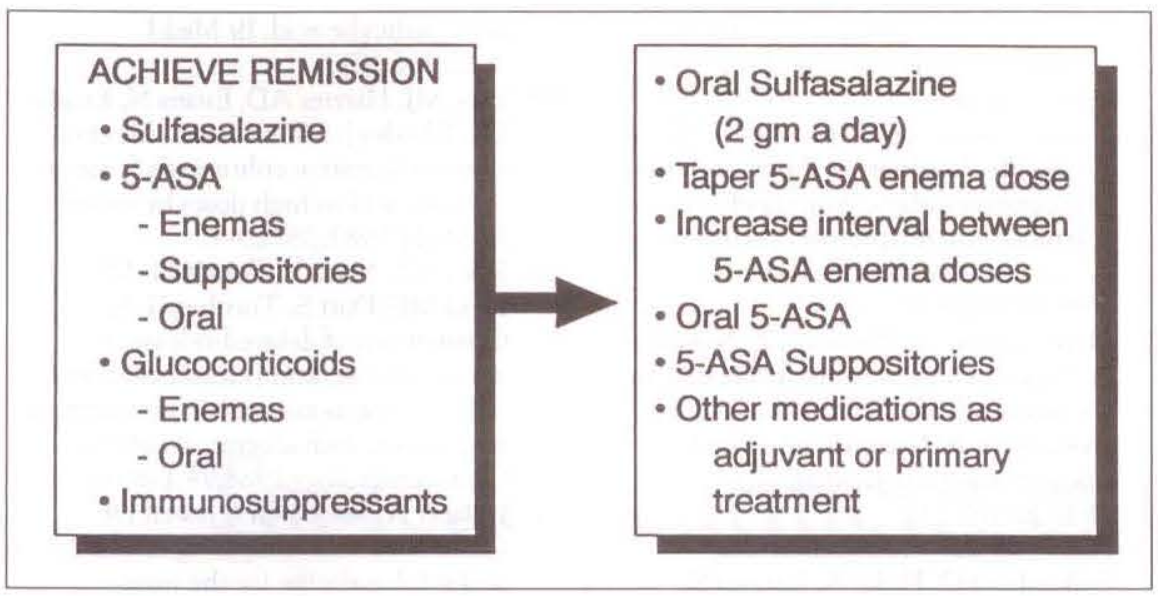

Figure 6) Strategies for achieving and maintaining remission in ulcerative colitis and proctosigmoiditis. 5-ASA 5-aminosalicylic acid

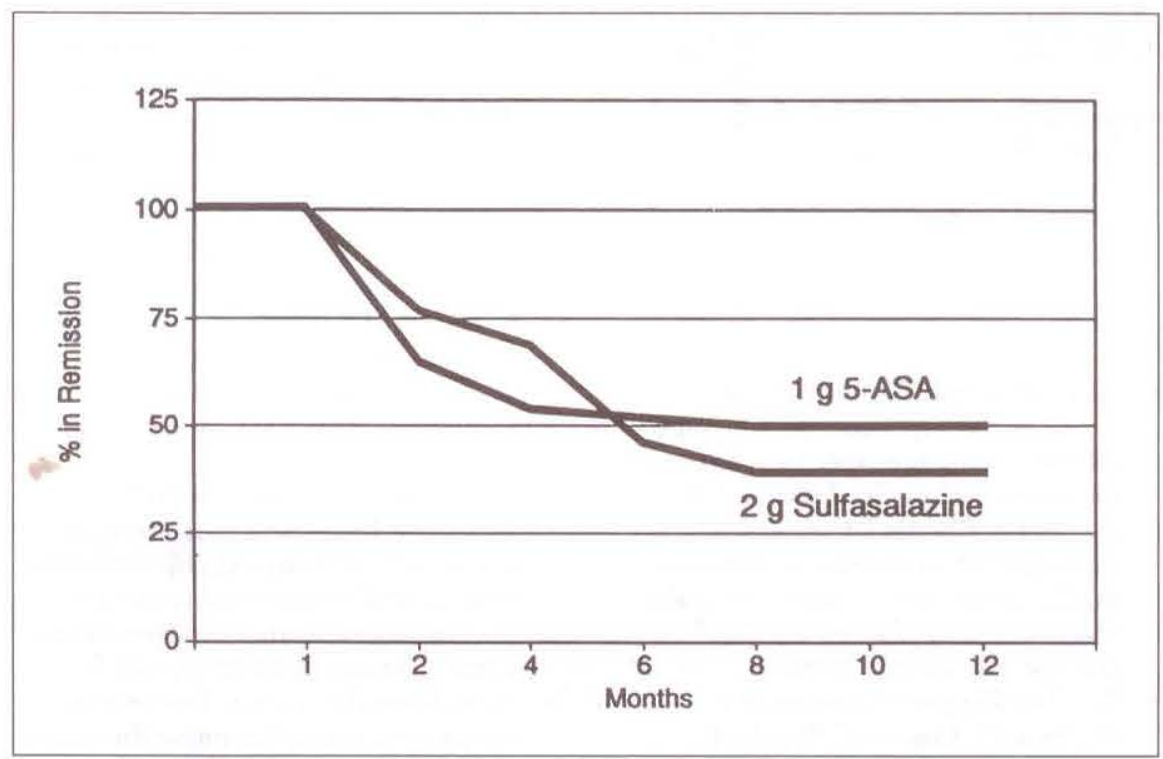

Figure 7) Percentages of patients maintained in remission with either $1 \mathrm{~g} 5$-aminosalicylic acid (5-ASA) or $2 \mathrm{~g}$ sulphasalazine over 12 months

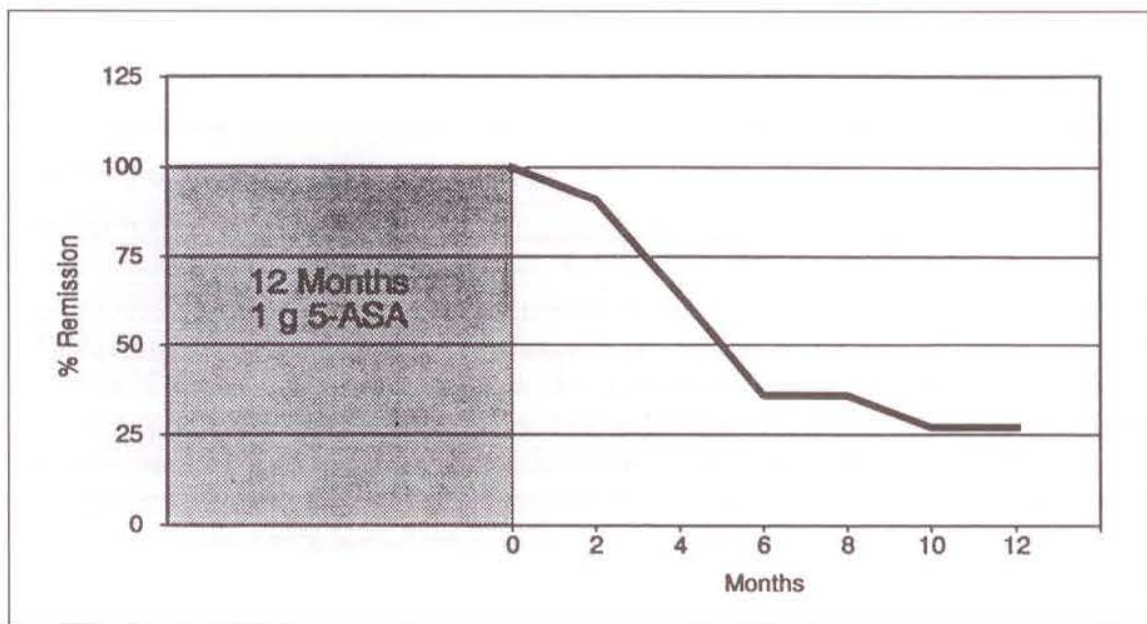

Figure 8) Percentages of patients maintained in remission on no medications after being maintained in remission on $1 \mathrm{~g} 5$-aminosalicylic acid (5-ASA) for one year of the study did not need medication, the authors evaluated the rate of remission after discontinuing all treatment in the 11 patients who maintained remission for one year on $1 \mathrm{~g}$ 5-ASA (Figure 8 ). The rapid return of symptomatic and proctoscopic disease suggests that the low dose 5-ASA enemas were effective in maintaining remission in these patients. Eight of these patients had been treated with high dose sulphasalazine prior to 5-ASA treatment. In these patients, sulphasalazine had been ineffective and remission was achieved on $4 \mathrm{~g}$ of rectally administered 5-ASA. They continued in remission as the enema dose was tapered to $1 \mathrm{~g}$ nightly, then were maintained in remission for one year. This suggests that maintaining patients in remission requires a smaller dose of 5-ASA than that required for inducing remission. Similar observations with the sulphasalazine dose required to induce remission compared to that needed to maintain remission suggest an important role for using lower doses to maintain remission. If properly controlled clinical trials of maintenance therapy confirm this observation, the higher cost of the 5-ASA formulations may be decreased by lower dose maintenance medications.

The authors have successfully used several strategies in order to maintain remission in patients who have gained control of their active distal disease with 5-ASA enemas. These uncontrolled trials have included: gradually tapering the enemas and replacing enemas with oral sulphasalazine; increasing the interval between enemas by using alternate day or every third day enemas; and decreasing the concentration of 5-ASA in enemas. The roles of these approaches in maintaining remission should be subjected to controlled clinical trials.

Most patients with distal ulcerative colitis will benefit from specific therapy designed to maintain disease remission. Strategies for maintaining patients with ulcerative colitis in remission should include sulphasalazine or one of the 5-ASA derivatives, as these medications are effective and exhibit minimal toxicity. 


\section{REFERENCES}

1. Morrison LM. Results of treatment of ulcerative colitis with salicylazosulfapyridine. Gastroenterology 1952;21:133.

2. Moertel CG, Bargen JA. A critical analysis of the use of salicylazosulfapyridine in chronic ulcerative colitis. Ann Intern Med 1959;51:879-89.

3. Svartz N. The treatment of ulcerative colitis. Gastroenterology 1954;26:26-8.

4. Lennard-Jones JE, Misiewicz JJ, Connell AM, Baron JH, Avery Jones F. Prednisone as maintenance treatment for ulcerative colitis in remission. Lancet 1965;i:188-8.

5. Biddle WL, Greenberger NJ, Swan JT, McPhee MS, Miner PB. 5-aminosalicylic acid enemas: Effective agent in maintaining remission in left-sided ulcerative colitis. Gastroenterology 1988;94:1075-9.

6. Misiewicz JJ, Lennard-Jones JE, Connell AM, Baron JH, Avery Jones F. Controlled trial of sulphasalazine in maintenance therapy for ulcerative colitis. Lancet 1965;i:185-8.

7. Dissanayake AS, Truelove SC. A controlled therapeutic trial of long-term maintenance treatment of ulcerative colitis with sulphasalazine (Salazopyrin). Gut 1973;14:923-6.

8. Davies PS, Rhodes J. Maintenance of remission in ulcerative colitis with sulphasalazine or a high-fibre diet: A clinical trial, Br Med J 1978;1:1524-5.

9. Powell-Tuck J, Bown RL, Chambers TJ, Lennard-Jones JE. A controlled trial of alternate day prednisolone as a maintenance treatment for ulcerative colitis in remission. Digestion 1981;22:263-70.

10. Whorwell PJ, Whorwell GM, Bamforth J, et al. A double-blind controlled trial of the effect of sodium cromoglycate in preventing relapse in ulcerative colitis. Postgrad Med 1981;57:436-8.

11. Sandberg-Gertzen H, Jarnerot G, Kraaz W. Azodisal sodium in the treatment of ulcerative colitis. A study of tolerance and relapse-prevention properties. Gastroenterology 1986;90:1024-30.

12. Hermanowicz A, Sliwinski Z, Nowak A, Gajos L. The effect of levamisole on the maintenance of remission of ulcerative colitis. A 2-year double-blind study. Scand J Gastroenterol 1987;22:367-71.

13. Riis P, Binder V, Kristensen M, Folkenborg O, Holtz A, Jarnum S. The relapse-preventing effect of methyl-salazosulphapyridine compared to salazosulphapyridine during longterm treatment of ulcerative colitis. Scand J Gastroenterol 1979;14:257-60.

14. Willoughby CP, Heyworth MF, Piris ], Truelove SC. Comparison of disodium cromoglycate and sulphasalazine as maintenance therapy for ulcerative colitis. Lancet 1979;i:119-22.

15. Dronfield MW, Langman MJ. Comparative trial of sulphasalazine and oral sodium cromoglycate in the maintenance of remission in ulcerative colitis. Gut 1978;19:1136-9.

16. Azad-Khan AK, Howes DT, Piris J, Truelove SC. Optimum dose of sulphasalazine for maintenance treatment in ulcerative colitis. Gut 1980;21:232-40.

17. Davies PS, Rhodes J, Counsell B, Evans BK. Maintenance of remission in ulcerative colitis. Effect of an orally absorbed mast cell stabilizer. Am J Gastroenterol 1980;74:150-3.

18. Dew MJ, Hughes P, Harries AD, Williams G, Evans BK, Rhodes J. Maintenance of remission in ulcerative colitis with oral preparation of 5 . aminosalicylic acid. Br Med ] 1982;285:1012.

19. Dew MJ, Harries AD, Evans N, Evans $\mathrm{BK}$, Rhodes J. Maintenance of remission in ulcerative colitis with 5 -aminosalicylic acid in high doses by mouth. Br Med J 1983;287:23-4.

20. Riley SA, Mani V, Goodman MJ, Herd ME, Dutt S, Turnberg LA. Comparison of delayed-release 5 aminosalicylic acid (mesalazine) and sulfasalazine as maintenance treatment for patients with ulcerative colitis. Gastroenterology 1988;94:1383-9

21. Ireland $\mathrm{A}$, Mason $\mathrm{CH}$, Jewell DP. Controlled trial comparing olsalazine and sulphasalazine for the maintenance treatment of ulcerative colitis. Gut 1988;29:835-7.

22. Mulder CJ, Tytgat GNJ, Weterman IT, et al. Double-blind comparison of slowrelease 5-aminosalicylate and sulfasalazine in remission maintenance in ulcerative colitis. Gastroenterology 1988;95:1449-53.

23. Jewell DP, lreland A. Controlled trial comparing olsalazine and sulphasalazine for maintenance treatment of ulcerative colitis. Scand J

Gastroenterol 1988;148:45-7.

24. Campieri M, Gionchetti P, Belluzzi A, et al. 5-aminosalicylic acid suppositories in the management of ulcerative colitis. Dis Colon Rectum 1989;32:398-9.

25. Gilat T, Leichtman G, Delpre G, Eshchar J, Bar-Meir S, Fireman Z. A comparison of metronidazole and sulfa. salazine in the maintenance of remission in patients with ulcerative colitis. Clin Gastroenterol 1989;11:392-5.

26. Azad-Khan AK, Piris J, Truelove S. An experiment to determine the active therapeutic moiety of sulphasalazine. Lancet 1977;ii:892-5. 


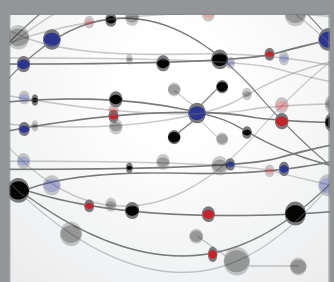

The Scientific World Journal
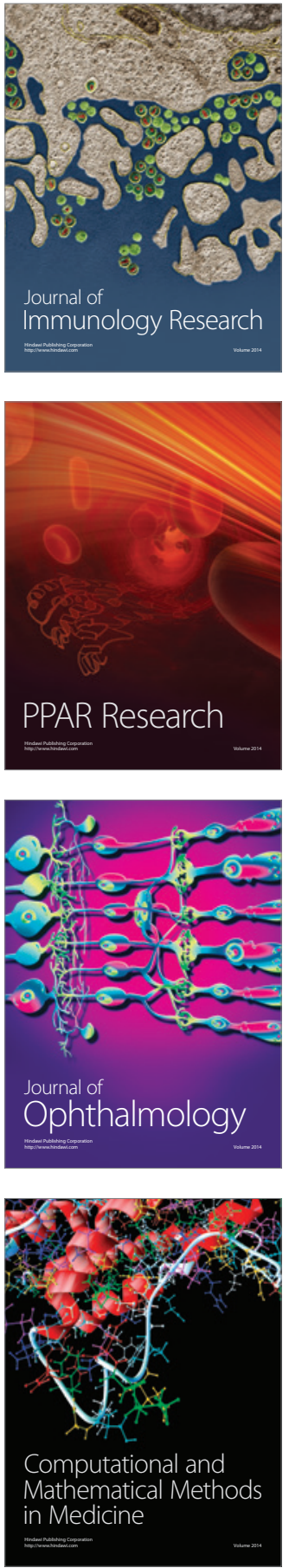

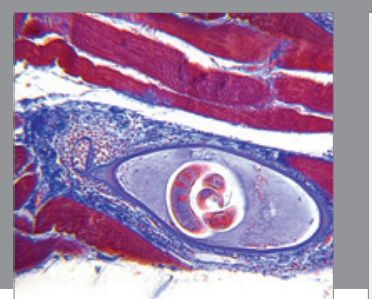

Gastroenterology Research and Practice

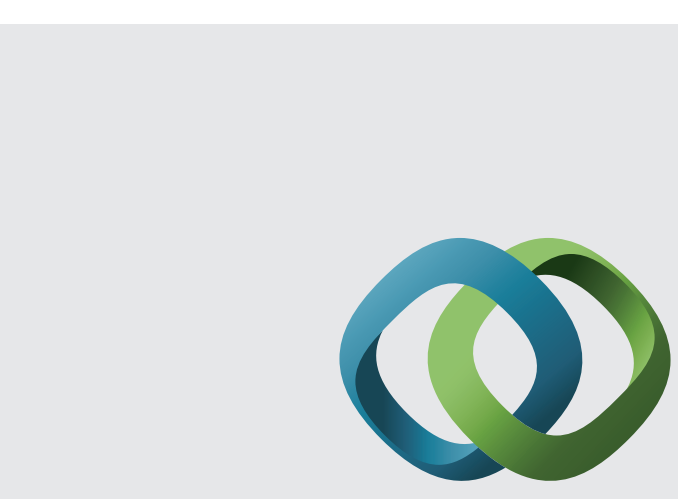

\section{Hindawi}

Submit your manuscripts at

http://www.hindawi.com
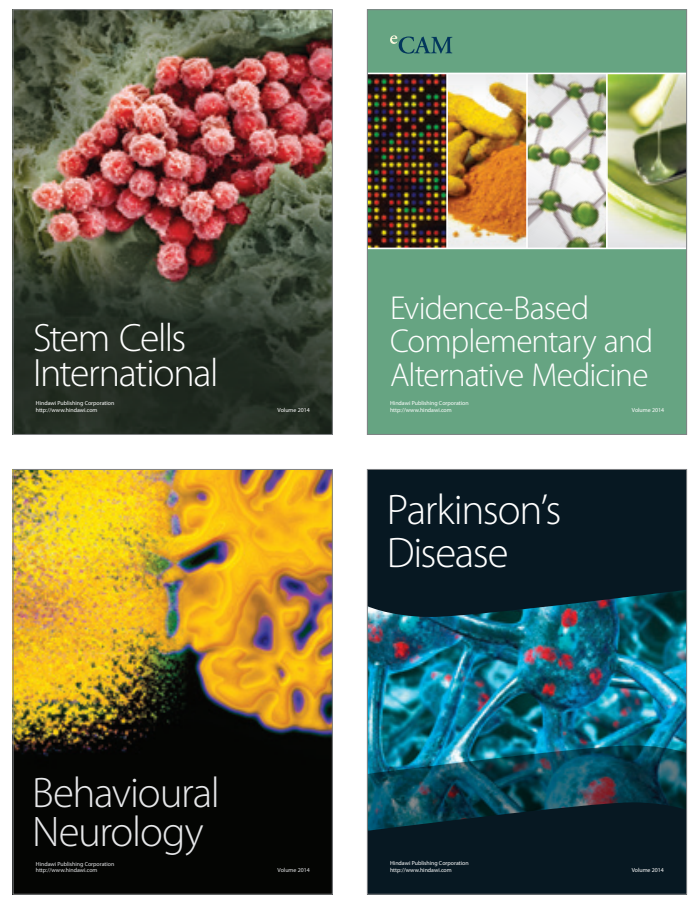
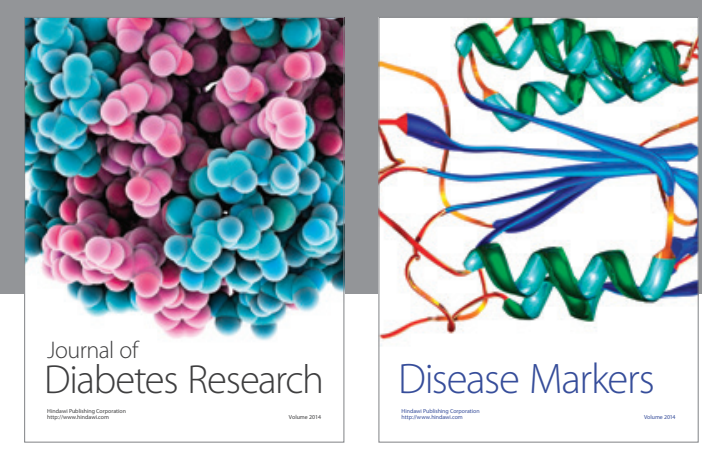

Disease Markers
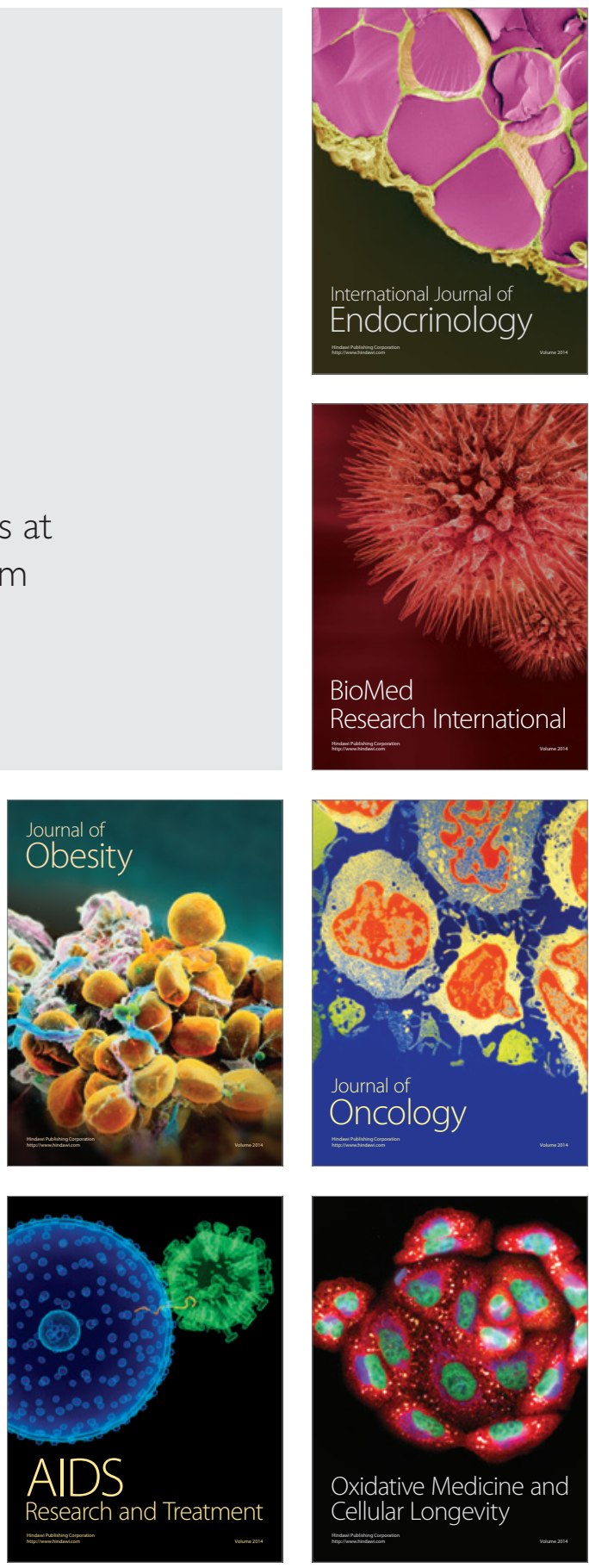